Relations industrielles

Industrial Relations

\title{
When Corporations Substitute for Adversarial Unions
}

Labour Markets and Human Resource Management at Magna

Quand les entreprises se substituent au syndicalisme

d'opposition

\author{
Le marché du travail et la gestion des ressources humaines \\ chez Magna

\section{Cuando las corporaciones remplazan los sindicatos hostiles Mercados de trabajo y recursos humanos en Magna}

\section{Wayne Lewchuk et Don Wells}

Volume 61, numéro 4, automne 2006

Pistes de renouveau syndical : défis et enjeux

Paths to Union Renewal: Challenges and Issues

URI : https://id.erudit.org/iderudit/014764ar

DOI : https://doi.org/10.7202/014764ar

Aller au sommaire du numéro

Éditeur(s)

Département des relations industrielles de l'Université Laval

ISSN

0034-379X (imprimé)

1703-8138 (numérique)

Découvrir la revue

Citer cet article

Lewchuk, W. \& Wells, D. (2006). When Corporations Substitute for Adversarial Unions: Labour Markets and Human Resource Management at Magna.

Relations industrielles / Industrial Relations, 61(4), 639-665.

https://doi.org/10.7202/014764ar

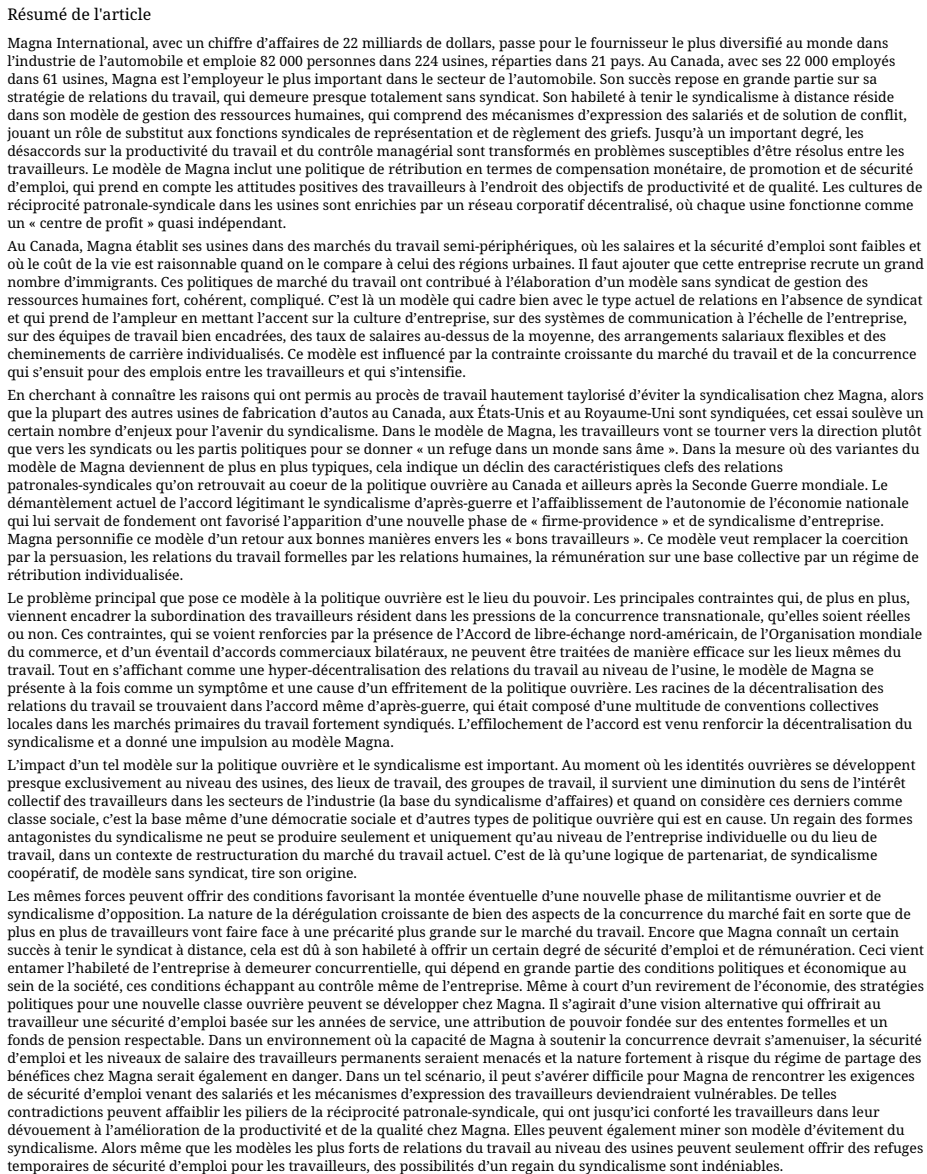

Magna International, avec un chiffre d'affaires de 22 milliards de dollars, passe pour le fournisseur le plus diversifié au monde dans dans 61 usines $M a g n a$ est l'employeur le plus important dans le secteur de l'automabile. Son succès repose en grande partie sur sa strategie de relations du travail, qui demeure presque totalement sans syndicat. Son habileté à tenir le syndicalisme a distance réside jouant un rôle de substitut aux fonctions syndicales de représentation et de règlement des griefs. Jusqu'à un important degré, les travailleurs. Le modèle de Magna inclut une politique de rétribution en termes de compensation monétaire, de promotion et de sécurité un " centre de profit " quasi indépendan. ' 'essources humaines fort, cohérent, compliqué. C'est là un modèle qui cadre bien avec le type actuel de relations en l'absence de syndic

En cherchant à connaître les raisons qui ont permis au procès de travail hautement taylorisé d'éviter la syndicalisation chez Magna, alor certain nombre d'enjeux pour l'avenir du syndicalisme. Dans le modèle de Magna, les travailleurs vont se tourner vers la direction plutôt ám qui lui servait de fondement ont favorisé l'apparition d'une nouvelle phase de “ firme-providence ” et de syndicalisme d'entreprise. re

作

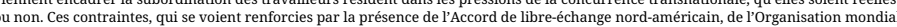
(a) syndicalisme et a donné une impulsion au modèle Magn

Limpact d'un tel modele sur la politique ouvrière et le syc collectif des travailleurs dans les secteurs de l'industrie (la base du syndicalisme d'affaires) et cunnd on considère ces derniers comme

classe sociale, c'est la base même d'une démocratie sociale et d'autres types de politique ouvrière qui est en cause. Un regain des formes (a) coopératif, de modèle sans syndicat, tire son origin sein de la société, ces conditions échappant au contrôle même de l'entreprise. Même à court d'un revirement de l'économie, des straté

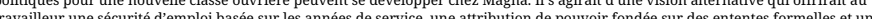
fonds de pension respectable. Dans un environnement où la capacité de Magna à soutenir la concurrence devrait s'amenuiser, la sécurité d'emploi et les niveaux de salaire des travailleurs permanents seraient menacés et la nature fortement à risque du régime de partage des dévouement à l'amélioration de la productivité et de la qualité chez Magna. Elles peuvent également miner son modèle d'évitement du temporaires de sécurité d'emploi pour les travailleurs, des possibilités d'un regain du syndicalisme sont indéniables.
Tous droits réservés (C Département des relations industrielles de l'Université Laval, 2006
Ce document est protégé par la loi sur le droit d'auteur. L’utilisation des services d’Érudit (y compris la reproduction) est assujettie à sa politique d'utilisation que vous pouvez consulter en ligne.

https://apropos.erudit.org/fr/usagers/politique-dutilisation/ 


\title{
When Corporations Substitute for Adversarial Unions \\ Labour Markets and Human Resource Management at Magna
}

\author{
WAYNE LEWCHUK \\ DON WELLS
}

The industrial relations system at Magna International is an example of an integrated, coherent, non-union human resource management strategy. It includes significant mechanisms of worker voice and conflict resolution as substitutes for union representation. Potential labour-management conflicts associated with Taylorized labour processes are often translated into group problem-solving. Redistributive conflicts are re-framed as mutual gains through profit-sharing. Corporate communications promote an ethos of competitiveness. Individualized pay and promotion schemes, segmented internal labour markets, and the exposure of individual plants to competitive pressures, promote cultures of labour cooperation in the pursuit of productivity gains. The success of this union avoidance model is situated in a context of the erosion of unionized labour relations, the disciplinary effects of precarious labour markets, and the vulnerability of workplaces to transnational competitive forces. Continued success is predicated on Magna's ability to survive sectoral and macroeconomic restructuring forces which are, in large measure, beyond management's control.

Magna International is the "most diversified automotive supplier in the world" with over 82,000 employees in 224 plants in 22 countries and

- LewCHUK, W., Labour Studies and Economics, McMaster University, lewchuk@mcmaster.ca

- Wells, D., Labour Studies and Political Science, McMaster University, wellsd@ mcmaster.ca

- The authors thank Mark Thomas, John Holmes, the McMaster working group on Workers and Social Cohesion, Magna employees and reviewers for this Journal. The research was funded by the Social Sciences and Humanities Research Council. 
annual revenues exceeding $\$ 22$ billion (Magna, 2006). In Canada, its 22,200 employees and 61 plants make Magna the country's largest auto sector employer (Magna, 2005a) and the fifth largest automotive firm in North America. Much of Magna's success depends on a labour relations strategy that is almost entirely non-union. This ability to remain largely 'union free' is built around a human resource management strategy focussed on active employee cooperation. ${ }^{1}$ The strategy includes significant mechanisms of worker voice and conflict resolution that substitute for union functions of representation and grievance handling. To an important degree, conflicts over labour productivity and management control are turned into problems to be solved among workers at the level of work groups. Magna's union avoidance strategy includes individualized monetary compensation, and promotion and job security rewards that are linked to each worker's positive attitudes to productivity and quality goals. ${ }^{2}$ Plant level cultures of workermanagement reciprocity are nurtured in a decentralized corporate network in which each plant operates as a quasi-independent "profit centre."

Union avoidance is reinforced by external labour markets. ${ }^{3}$ Magna locates most plants in semi-peripheral labour markets where wages and job security are poor, and living costs are moderate relative to major urban areas. Magna also recruits large numbers of immigrants. The result is a strong, coherent, sophisticated, non-union human resource management strategy that fits within the growing pattern of non-union workplace relations. As described by Katz and Darbishire (2000: 11), for example, this HRM pattern emphasizes corporate culture, extensive corporate communications systems, directed teams, above-average wages, contingent pay schemes, and individualized career development. At workplace level, these features are linked to mechanisms of union substitution integral to the emerging nonunion industrial relations system in the US, as described by Kochan, Katz and McKersie (1986: 47-80). At the macroeconomic level, these non-union trends are conditioned by the growing coerciveness of neoliberal markets and attendant increasing job competition among workers (McBride and Williams, 2001).

In exploring why the Taylorization of work at Magna has not led to unionization and the sort of worker resistance found in most large automobile plants in Canada, the US and elsewhere (Beynon, 1975; Humphrey, 1982; Jefferys, 1986; Graham, 1996; Wells, 1995, 1996) this paper raises a number

1. For an early study of Magna, see Anderson and Holmes (1995). On labour-management cooperation in a team-based "entrepreneurial" culture, see Stewart (1989).

2. Magna's strategy is consistent with findings in Foulkes' study of human resource management systems in large US firms (Foulkes, 1980).

3. Cf. linkages between the growth of non-union industrial relations systems and labour market changes in the US (Kochan, Katz and McKersie, 1986: 52-55). 
of implications for the future of unions. In the Magna model, workers look more to management than to unions or political organizations to provide a 'haven in a heartless world.' To the extent that variations on Magna's model are becoming more typical, this suggests a decline of key features of labour-management relations that were central to the 'making' of post-war working class politics.

\section{RESEARCH METHODOLOGY}

The findings stem mainly from research at two Dortec plants of Intier Automotive, one of three automotive divisions of Magna International. ${ }^{4}$ Dortec is a subsidiary of Intier, which has 24,100 employees in seventyfour sites in North America, Brazil, Europe and Asia (Magna, 2006: 19). The analysis is based on the authors' extensive direct observation of work relations, corporate documents, interviews with auto industry analysts familiar with Magna, interviews with plant and corporate-level Magna managers, and interviews with production workers. The employees who were interviewed were selected under the authors' direction by managers using criteria specified by the authors, including varied seniority, gender, skill and jobs. This yielded a stratified cross-sectional sample of eighteen workers. While there may have been some management manipulation of this selection, the authors are confident the interviews were broadly representative of attitudes of many workers in the plant. This is supported by a separate set of interviews with six injured workers, laid off by Magna, who volunteered to be interviewed at a worker advocacy centre. Their view of work at Magna was consistent with that reported here. Questions for these semi-structured interviews were devised and administered by the authors. Workers were interviewed separately by one or both authors and were guaranteed that their responses would be confidential. Interviews typically lasted an hour. The authors did open-ended interviews with four government and private sector auto industry analysts, two corporate-level and five plant-level Magna managers. The authors observed work arrangements in three Magna plants, two at the complex described above and another in a different community.

\section{WORKING AT MAGNA}

The "campus" of the factory complex that is the focus of this study consists of a half dozen carefully landscaped brick structures surrounded by a large upscale housing estate. Inside one of these structures, over

4. The other divisions are Decoma International and Tesma International. 
400 people manufacture automotive latches, opening devices and door modules. The facility is composed of a stamping plant, an assembly hall, and a tool and die shop. The assembly hall is divided into dozens of selfcontained work areas, each set up to make one of the dozens of small components. A typical work area employs eight to ten people. The jobs themselves are carefully engineered cells. Tooling technology is creative but not cutting edge. There are no robots. Most workers are employed loading, assembling and unloading components on jigs and fixtures. The work is fast and repetitive. Cycle times are typically less than a minute, and the assembly jobs require little skill. At about $\$ 16.00$ an hour, wages for most of the production workers are modest: about average for the parts sector, but about $40 \%$ less than pay for comparable work in a vehicle assembly plant (APMA, 2003).

Given this highly Taylorist labour process, the cooperative nature of workers' relation to management is striking. An assembler: "I really like my job. The line that I am working now is my favourite line." A press operator: "I like coming to my job. I enjoy what I do.... I enjoy the people. We have fun." Another assembler: "I love doing well. Like I love keeping up." A tool and die maker: "From what I see there's a lot of pretty happy people here." Several workers we spoke with regularly exceeded required effort norms. An assembler:

"Our quota [on another line] was 180 an hour and ... we used to make like 240 parts an hour, sometimes 270. Way out of quota and [workers] pushed, pushed, pushed. . . . It almost becomes like a competition ... where you can just see if you can do more, more, more.... I still get it sometimes here when I'm on a machine where I'm by myself and there's nobody after me... . You just go, go, go."

Although none of those interviewed were 'happy workers' exhibiting profound fulfillment in their deskilled, routinized jobs, most reported surprising satisfaction with their work and an active commitment to Magna's corporate goals. Much of the literature on cooperative labour relations focusses on 'post Taylorist' labour processes (Ross, 2003; Appelbaum et al., 2000; Zuboff, 1988; Adler, 1992) built around less standardized and less authoritarian forms of work organization. Nor does worker cooperation at Magna stem from upward-skilling socio-technical production systems found, for example, in some Swedish plants (Brulin and Nilsson, 1997; Bengtsson, 1999; Berggren, 1992). Nor is the Magna model built around the multi-skilling and small group problem-solving associated particularly with Toyota production systems in Japan (Koike, 1987; Cusumano, 1985). The remainder of this paper explores how Magna has gained the active cooperation of its workers and avoided unionisation, without radically changing the nature of work. 


\section{THE MAGNA MODEL}

Magna's high commitment model has evolved over five decades, beginning at a small tool and die shop in 1957. As major auto assemblers increasingly outsourced production to components manufacturers, Magna diversified its production and design capacities to join the ranks of large first-tier suppliers. Magna expects sales to reach $\$ 50$ billion within the next ten years. In Canada, Magna is now the largest auto employer with annual revenue second only to General Motors.

\section{FIGURE 1}

\section{Canadian Employment by Company, 2005}

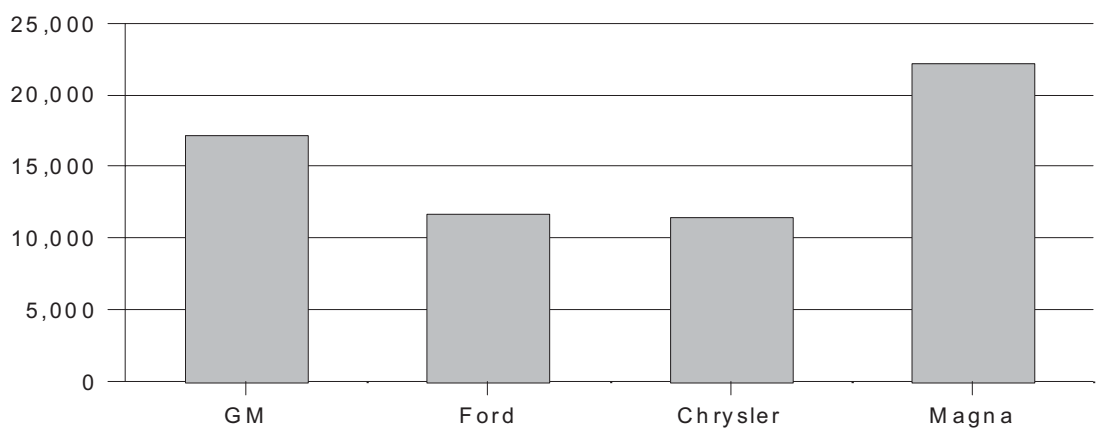

Source: Magna (2006); CAW 2005 Big Three Bargaining: Facts and Figures, July 2005.

In contrast to 'big factory' Fordism, with its mass, centralized workforces, Magna employs its tens of thousands of workers in hundreds of plants, each with a few hundred workers, allowing Magna to incorporate elements of a paternalistic management strategy while magnifying the exposure of workers and local managers to competitive pressures. ${ }^{5}$ Magna's plants are semi-autonomous and more directly exposed to market discipline than is the case in production units integrated into large plants. The corporate centre provides financial resources, a forum for exchanging ideas and developing best practices, and shapes company philosophy, including the organization of workplace culture. This combined centralization and decentralization captures synergies of small-firm networks. ${ }^{6}$ Strategically,

5. The average plant employed 283 in 1997 and 366 in 2005 (Magna Annual Information Form, 1997-2006).

6. On benefits of auto related clusters, see Holmes et al. (2005). 
the company is a single firm industrial district in which operating units take on features of small and medium-sized firms, as described by Sabel, citing Magna as "an extreme case in point" (1994: 122). Magna refers to this strategy as one of "functional and operational decentralization" (Magna, 2006: 12).

\section{MANAGEMENT'S OPEN DOOR}

Magna's HRM strategy shapes an ethos in which harder edges of management control are softened by a culture of worker-manager reciprocity. From job advertisements promoting it as a "Fair Enterprise Employer" to the widely displayed "Magna Employee Charter," Magna brands itself as caring about its workers. This culture is fostered by an air of egalitarian informality in day-to-day shopfloor relations. Both plant managers and workers have an average age in the mid 30s, and this informality is, for many, part of a shared generational bond. In many production areas, women represent the majority of the workforce. A number of line leaders were women, but very few work in the trades.

Magna's HRM strategy centres on worker voice mechanisms, corporate communications, and problem-solving work groups. Worker voice is channelled through a grievance system that substitutes for formal "due process" in unionized workplaces. Through its Open Door Policy, Magna encourages workers to articulate concerns not as collective grievances requiring worker resistance and higher level negotiation but as individual problems to be solved informally on the shop floor. Indicative of Magna's success in this regard, workers we interviewed saw line leaders and supervisors as reasonably impartial adjudicators helping to deal with workers' concerns. To avoid any escalation of conflict, management policy is to respond to any concern within 48 hours. A line leader explains:

As soon as a group of people start talking about an issue, the management actually starts to get on it real quick ... before it can start going through the whole issue. And then within 48 hours or something management will have a response for that group of people.

For some, Magna's Open Door Policy is "like a union." Others feel a union grievance procedure provides more protection because "at least they are there to back you up.... [At Magna] if you don't get a bunch of people to back you up, you are just on your own." A worker who had worked in a unionized plant explained that the union provided "more protection," whereas at Magna "you don't really have that much protection." A line leader reported, for example, that although workers know they can use the Open Door Policy, they prefer not to. "I don't know if they're afraid to or they feel that if they do ... there might be some kind of repercussion." 
And a worker suggested that if management "decides to get you on your attendance, that's it. . Y You're out the door." Legal consultants reported that a number of Magna workers have lost their jobs following work-related injuries. ${ }^{7}$ For others, however, including this tool and die maker, Magna's procedure is still empowering but only for workers as individuals:

GM's a unionized plant where you go through your Committeeman and every other process. Here ... if my foreman has a problem with me or my supervisor does, I can go in that office and talk to him one on one, and I don't need a third party involved. And we can fix it up pretty quickly.

Magna's Open Door Policy also includes formal mechanisms. For example, any worker may raise concerns with the Employee Advocate, an hourly employed who is selected by management, but who can only be removed by at least half the voting workforce at periodic secret ballots (Magna, 2005b: 29). The Advocate seeks out workers' concerns, provides management-sanctioned options, and sometimes accompanies workers to meetings with management. However, as a Magna manager clarified, the Advocate is "not to represent" but to "guide and assist where needed" rather than to "take on the lawyer role." Expressing a common attitude among workers, an assembler explained:

[The Advocate is] a guy from the floor. We've worked with him before, and any issue you have, you can go to him.... And you can tell him your problem and he's coming back to you in a few hours or a few days, depending on how big is your problem. He is a very nice guy. I had a very good experience with him.

Workers may also take unresolved grievances to Magna's Fairness Committee, composed of managers and employees elected by their peers. "Our whole reasoning behind the Fairness Committee and the Employee Advocate," explained an HR manager, "is to sort of bridge that . . . missing link between employees and management, and to help foster the Open Door Policy." Like the Employee Advocate, Fairness Committee members may accompany workers to meetings with management, but do not speak for them. A worker who served on a Fairness Committee explained that the Committee learned "how to make people understand."

A worker who is still not satisfied may appeal to corporate-level management by calling a "Hotline," but this is rarely used. Plant managers prefer employees to "have enough confidence in our Management Team to give us a chance to solve the problem first." (Intier Automotive, n.d.). Indeed, all the steps in Magna's Open Door Policy beyond first line supervision are rarely used, mainly because workers usually resolve

7. Personal communication, April 2005. 
job issues (e.g., job rotation, minor changes in job sequences, overtime allocation, etc.) themselves.

The key to workers' resolving most job issues lies in Magna's work group organization. Varying in size from three to eighteen or more, work groups are smaller than supervisory zones or production departments in most Big Three assembly plants, and thus easier to manage. Their size also contributes to a more personal relation between line leaders and workers, and between front line supervisors and workers. An assembler reported: "we all kind of kick in together and help each other. . . . It's almost like a little family." An assembler:

We rotate our job every hour, so I know all sixteen, seventeen jobs on that line, and we also know everybody. We know each other, we know how we work, we know where the bottleneck[s] of the line [are], and when I have extra time I know where I should help out.

Work groups meet frequently. A line leader:

We meet ... any time we have an issue. Like, I ask them every day, 'How can we improve things?,' 'How can we make things better?'... Just the line itself meets every day and we sort of talk about ways to improve things.

For the most part, work groups solve narrow problems related to productivity within their areas, and then make recommendations to management. Typical issues involve workers' concerns about floor mats in the area and the pencils they use. Line leaders and supervisors play major roles in working out problems through work group consensus. Supervisors "supervise like a friend" and are "easy to talk to," an assembler points out. The line leader, who has a day-to-day relation to the workers, is a communicator and mediator, not an order-giver. Through leaders, management inserts supervisory roles into the work groups, blurs the line between management and worker, and provides a significant buffer to potential resistance, changing potential labour-management conflicts into problems workers solve in relation to each other.

Given the limited role of seniority at Magna, workers often use personal relations with supervisors to make individual gains, such as better access to training and job postings, preferred vacation schedules, and hiring of friends and family members. Supervisors typically suggest training for particular workers, and this can play a major role in promotions. Supervisors and line leaders favour "people with positive attitudes," reported a line leader. Magna's less bureaucratic employee relations system makes it easier for managers to reward employees they consider meritorious. This is an important basis of informal reciprocal manager-worker obligations. "I come in and I'll give [the supervisor] a fair day's work, so he'll treat me with respect," explained a tool and die maker. "That comes back where I'll ask 
[the supervisor] to do something, [the supervisor will] do it." At the same time, it is recognized that without a union these reciprocal relations are based on highly unequal power: [elsewhere] "a lot of people hide behind the union. That's their safety barrier. In here you can't get away with that [because] basically if you don't want to do the job, okay, guess what? You're fired." Some workers view this inequality in power positively as a way to ensure that workers follow management directives, thus ensuring profits which benefit individual workers through Magna's profit sharing plan.

Another mechanism of worker voice is Magna's Quality of Work Life Survey, which is designed to monitor how well local management fulfills Magna's Employee's Charter. The Charter outlines the firm's "operating philosophy" based on "fairness and concern for people." Common questions allow management to benchmark quality-of-work-life responses across Magna plants. When the survey discloses significant problems, plant managers set up Quality of Work Life Action Teams and Employee Focus Groups to develop action plans. Workers and managers discuss the survey results and action plans at plant, department and work group meetings.

\section{CORPORATE COMMUNICATIONS}

At Magna, mechanisms of worker voice overlap with internal corporate communications. Throughout the plants there are Communication Centres that include employee suggestion boxes and information about job postings, company stock values, plant performance, company events and other activities. During weekly Department Meetings and daily Line Meetings, line leaders and supervisors report on "how we're doing, if they're making money, if there's new lines starting. ... [They] let you know everything about the business," says an assembler. Based on these discussions, line leaders make weekly reports that workers read before the reports go to management. "It's kind of like voting," a line leader explains. "We read [the report] with the group ... If they agree with it, then everyone has to start following it." Sometimes managers attend the line meetings to reinforce compliance. One manager brings pizza to line meetings when work groups meet their quotas. At monthly Plant Meetings managers tell workers "if we're doing well or we're on the low side," a production worker reports. Workers ask questions and managers "give us whatever information they have." A line leader: "They show us slides of what our quality percentage was for the month, and what our productive measures were for the month, and everything else about it."

Sometimes, when business is going less well, management's message to the workers can be negative. For example, management has talked about 
adverse market conditions requiring the firm to reduce fringe benefits. Usually, however, the message is one of competitive success in which everyone has played an important role. A tool and die maker:

Every meeting they're always thanking us for doing a good job, and always. . . trying to make, you know, a little more effort. They don't come out and say 'work harder,' or whatever. They say 'fantastic job.'. . that's the best way to motivate someone to do a good job.... [managers] always credit everyone in the monthly meetings. Everyone as a whole is making this happen.

There are raffles at the meetings and workers who have perfect attendance get chances to go on weekend retreats. Every month, management invites workers with birthdays that month to Coffee Chats where managers inform them about business activities, such as new contracts. The Plant Meetings and Birth Month Meetings bring together a cross-section of the plant employees including production, skill trades, supervision, technical workers and managers, reinforcing plant-wide identities rather than just work group, departmental and skill-based identities.

Management also uses training as corporate communication. Much training centres on production quality, such as training work groups in introductory Six Sigma (a system of quality management that uses statistical measures to orient employees to efficiency improvements) and 'soft skills' to help workers achieve quality and productivity goals in cooperation with others. Management also uses sports to increase its bonding with employees. Magna has a park with water sports and other facilities for employees and their families. There are also numerous employee events, including an annual 'hoe down' at corporate headquarters, and tickets for employees to attend cultural events.

\section{SENIORITY RIGHTS AND MANAGEMENT RIGHTS}

Magna workers have limited formal contractual rights. Most entitlements are customary and subject to management discretion. This includes seniority rights. At Magna, seniority is a factor in promotions only where two candidates are deemed equally qualified by management. Promotion requires good work records and cooperative attitudes. According to the employee handbook, "promotion means giving a broader service and a greater commitment." Seniority is more important in lateral transfers (e.g., to another shift), but those with discipline infractions or whose work is deemed unsatisfactory are ineligible. Seniority has little bearing on job transfers to other Magna plants. Finding a new job within the Magna system largely depends on managerial discretion.

This limited role for seniority provides management with far more flexibility than it would enjoy in most unionized plants. Nevertheless, to 
the extent that seniority is a residual factor in such decisions, employees sense a degree of due process and protection from discrimination. While seniority has, at best, a minor role in the employment security of permanent workers, those we interviewed felt considerable security. This partly reflects the job security buffer of temporary workers in these plants. Job security has also been reinforced for the past decade or so by growing employment at these plants and at Magna as a whole. This security underpins the cooperation many workers give to management, particularly in promoting job-eliminating improvements. Especially for many immigrant and female workers who face disproportionate inequalities in external labour markets, this level of job security is likely to be especially powerful in shaping their active cooperation with management.

In effect, Magna combines some job security advantages of a large firm with paternalistic, personalized labour relations that are possible in smaller plants. In particular, individual rewards for achieving management goals are much greater than in most unionized plants. Individual job security and job mobility inside the plants promote an ethos of individual success that masks the underlying collective inequalities of labour-management relations. Workers who want to 'get ahead' have potential advantages, and some feel that seniority rights protect workers who do not work very hard, thus dragging down profitability and reducing overall employment security.

\section{CONSULTATIVE WORK RESTRUCTURING}

Labour-management consultation mechanisms focussed on work restructuring lie at the intersection between corporate communications and worker voice. While work groups focus on minor issues, major changes are usually designed by cross-functional teams made up mainly of engineers, other technical personnel and managers. A line leader explained:

When it comes to actually making changes on the line, or rearranging the line, or how things should be done, it's all the management that does that. I mean we can put in suggestions and comments and stuff about how we think it should be, but then management has to go through the whole process of looking it over, seeing how feasible it is.

Management's unilateralism, an assembler explained, is based on apparent technical imperatives:

Even if people don't like [changes in the labour process], sometimes it's like a law. They can't [change it]. [Managers] say 'sorry people, but we can't do it.' They said 'there are the rules.' They have to follow some interests from the [technical design] table to the machine. 
A line leader reported that managers "just come in and say ok, this is the way the line is. Deal with it." "If you are not management," he's noticed "you won't get a hell of a lot done."

Such consultation is not without contradictions. Changes are often about making work faster and adding tasks to jobs. Some changes entail job elimination. An engineer explained that he is responsible for introducing automation to eliminate jobs by calculating the cost of machines compared to wage and benefit costs. When engineers "come out with a stopwatch, holy smokes, the line slows down cuz they know we're timing them to see where we can make improvement and they feel threatened." When changes mean work intensification, "that does really make us mad," a line leader explained.

Even when worker consultation about job changes entails little productivity gain, it may foster worker internalization of management's enthusiasm for increased productivity. Alignment of one's identity to the attainment of common goals with other workers partly immunizes many workers against the discontents of heavy workloads and repetitive labour. Management claims employees enjoy "an appropriate level of autonomy and responsibility so they consider each operation as though it were their own business."

\section{CARROTS AND STICKS}

Communication, worker voice and consultation policies help defuse labour-management conflicts while encouraging workers to consider themselves key players in Magna's success. Also significant in promoting such unitarist industrial relations is the company's compensation strategy. Wages are modest for the sector, about average for the parts sector but about $40 \%$ lower for assemblers and $15 \%$ lower for skilled categories compared to Big Three assembly plants. Benefits are also much lower than in Big Three plants. Work shift premiums at the Big Three, for example, are two to four times those at Magna, and there are substantial differences in paid time off, including holidays and vacations. ${ }^{9}$

Despite compensation inequalities, there is a general sense that Magna wages are "good ... for what I do." In the context of external labour markets where many workers receive few if any benefits, Magna workers value their

8. www.intier.com/WorkingIntier/Working_Intier.html.

9. After one year, Magna employees received 192 hours of paid time off per year compared to 284 hours at GM; after ten years the ratio is $272: 360$ in favour of GM; after 25 years it is 312:420 (Intier Automotive, n.d; CAW-GM Master Agreement, 2002). 
benefits. A former GM skilled trades worker said his pay was less than two-thirds of his GM wage, but that he was satisfied with his wages, in part because he is treated well at Magna whereas at "GM you're a number." When workers talk about wages and benefits at Magna, they often compare them to worse wages and benefits at previous jobs. Acceptance of modest wages is also explained by an internal labour market that is divided between permanent full-time workers and a tier of temporary workers comprising up to a quarter of the workforce. New hires start as temporary workers with lower wages and without profit-sharing or pensions. They endure probations of several months to years before managers select some for permanent jobs. Temporary workers are a reminder to permanent workers about how fortunate they are, particularly since many permanent workers were once temporaries.

The pay system stresses contingent components that reflect individual worker cooperation and the vagaries of financial markets. Annual pay increases, profit shares and benefit coverage are linked to overall firm performance. Under the "pay-for-performance system," each worker's annual pay increase depends on annual performance reviews by supervisors. Criteria include productivity, quality, attendance, safety and housekeeping, job knowledge and reliability, and criteria such as "adaptability," "communication," and "decision making" (Intier Automotive, n.d). Workers who do not meet management's expectations receive only half the pay increase, and are eligible to receive the rest only if their performance improves. Meeting performance criteria in any year triggers a return to the full wage level. An assembler feels these evaluations are "like getting a report card."

[The supervisor will] say 'you're a good worker. You work safely.' And then she'll talk about my attendance and then she'll say that I help other people and I like to save time. Like, if my line is down, I like to be, you know, like doing something else, not just standing there. You know, [supervisors] always let us know how we're doing.

There are significant individual incentives for workers whose skills are especially needed or whose efforts are exemplary. Those with perfect attendance participate in monthly draws to win financial bonuses or additional time off. At some plants, management gives each full-time permanent worker an annual bonus of perhaps a few hundred dollars based on local production targets. Magna presents workers with Service Awards to recognize "long service and loyalty" (Intier Automotive, n.d.: 20). Workers earn "reward points" and prizes for making suggestions accepted by management. Although the scale of most workers' suggestions limits their value for cost cutting and productivity improvements, such participation is consistent with internalizing 'continuous improvement' goals. 


\section{SHARING THE PROFIT PIE}

Perhaps the most effective mechanism encouraging workers to promote management goals is the Deferred Profit Sharing Plan. Magna distributes $10 \%$ of annual pretax profits to employees in the form of company shares that are held in individual trust accounts. Most employees are not allowed to make withdrawals from these accounts for at least ten years. An optional Defined Benefit Pension Plan, which provides a fixed pension at age 65, includes a lower level of profit-sharing. Most employees, reportedly over 90\%, choose the Deferred Profit Sharing Plan. After choosing an option, a worker may not make a different choice. Since 2005, Magna has closed the defined benefit option to new employees (Magna, 2006: 27).

Magna's Employee Handbook urges employees to "help the profit sharing plan by being aware of how you affect the profit of your Company . .. Teamwork makes it happen!" Since Magna share values have historically been volatile, profit sharing constantly reminds workers of the competitive world in which the company operates. The deferred aspect of the profit sharing plan means the ultimate value of current profits will depend on the firm's long term performance, thus further aligning worker interests with company success. In contrast to pension plans where the employer contribution is viewed as a drain on corporate capital, deferred profits invested in Magna shares are a source of corporate capital.

About $60 \%$ of employees also participate in a Group Registered Retirement Savings Program which allows employees to allocate a percentage of their earnings to the plan. For those not opting for the fixed pension, Magna partially matches the employee contributions. There is no match for employees participating in the fixed pension. Since few opt for the fixed pension, most rely on profit-sharing as their main source of retirement income. Indeed, some have voluntarily purchased thousands of dollars of the firm's shares over and above the shares they already hold through the profit sharing plan, thereby increasing their dependence on Magna's success. After years of company growth, this strategy has paid off, but lack of diversification makes it a risky financial strategy (as evidenced by a 30\% fall in Magna's share price over two years since 2004).

These investments in company equity are succeeding in aligning workers' job efforts to corporate profitability. While engineers and managers tended not to see a strong link between their work and company profits, most production workers felt there were links between how they worked and Magna's stock values. A production worker said when some workers damage tools or cause waste in production, other workers say "Look it, that's coming out of my pocket, you idiot!" This can cause "heated discussions" among workers. A line leader said she tried to keep quality high so parts 
wouldn't be rejected. She felt this meant corporate profits would be higher and there would be more profits for her to share. A line leader considers himself a "small owner" of Magna because of the profit sharing plan. His work affects the company's stock price because "if it costs more to make the part, we're gonna lose." Another line leader suggested:

The people [in the plants] ... like to make sure [quality is high] ... because [otherwise] it will look bad on us and it will look bad on the business and we might lose business over this... If you lose this, then they know they won't have a job....like they'll be reading a newspaper and they'll [read] that Ford's having a lot of rejects or that the stocks have gone up. Again, we do talk about that, because when it comes to that type of stuff it sort of has to do with job security and how much money you are going to make.

Another line leader: "So everyone's kind of made up to be 'ok, let's give [management] what they want. This way [with profit sharing etc.] no one's complaining. ... It's kinda like 'let's give 'em what they want."'

In other cases, however, some have been less willing to cooperate with management goals. A skilled worker explained that he might "not feel that management per se is necessarily on our team but as a group we tend to stick together and that's what I think is the team." In a workload dispute, the workers in his group "voiced their opinions" but most did not want to complain to management, fearing they would "upset management or whatever, and then have it turn around and come back at them." In extreme cases, work groups have resisted management with some success. One worker recalled an episode where skilled workers felt management had been unfair to an injured worker in their work group. When they threatened to down tools, managers quickly resolved the crisis to the work group's satisfaction.

For the most part, Magna's culture precludes such resistance through a web of workplace dependency. Management control centres on the interdependent functioning of specialized roles: engineers, quality control, human resources, plant managers, assemblers, tool and die makers, and supervisors. These must function together if plants are to succeed in the competition for contracts. This interdependence signifies neither equality nor complete unity. Workers have a sense of an "us" and management as "them," but the differences constitute an essentially unitarist labourmanagement relations system in which almost everyone is substantially oriented toward common productivity and profit goals. "We're all part of a group to achieve the same goal, right?," a line leader explains. "I look at the whole plant as being one team. Because, I mean, even if, say, one line down at the back screws up, and stuff like that, it affects all of us." Moreover, there appears to be a general sense among permanent production workers that plant management is, with some exceptions, 'fair,' and that reciprocal obligations in the Magna Charter are being fulfilled, more or less. 


\section{LABOUR MARKET DISCIPLINE}

The active consent of many of these workers to management goals and their attitudes to unions are also linked to their work biographies. Many came to Magna after working in peripheral labour markets: jobs at farms, restaurants and convenience stores, often in rural areas and economically depressed regions. Many are women without technical credentials, and many are new immigrants from low labour standard areas in Southern and Eastern Europe and Asia. One of these immigrants captured the benefits that hiring such immigrants has for Magna.

I came from Hong Kong. I never saw this policy here that we have a hotline to complain ... that never happen in Hong Kong. ... Wow! This is why I like this company. ... This is why I think I have something, I have a very good support on job security here and I believe that people have to work hard in order to get what they want.

Most had no experience of collective gains through labour militancy and solidarity in unionized workplaces.

Internal and external labour markets operate as carrot and stick. Magna's 'carrot' is that, based on two incomes, many of its permanent workers earn a 'family wage,' own a home and have a reasonable level of job security inside these plants. The 'stick' lies outside. While wages inside the plants are lower than those in core labour markets, such as auto assembly, they are higher than wages in peripheral labour markets outside the plants. Recent external labour market trends are reinforcing their disciplinary effects. From 1989-2001, those in the bottom 60\% of family market income in Canada experienced declining market income. ${ }^{10}$ Meanwhile, the share of employees in precarious employment increased by a third (Vosko, 2006: 22).

Magna also benefits from hiring through family referrals. Many workers we interviewed had relatives working at the same plant. Use of family referrals, particularly from ethnic labour pools, contributes to company loyalty and subjects workers to group discipline. There are two and three generations of some of the families and there may be fifteen or twenty members of a family working at a plant. Magna's "family" is a "family" of families. A line leader:

I've never seen a place with so many family members all in one place. And you look at our plant floor and stuff and you've got cousins and nephews and uncles and aunts and brothers and sisters and wives and fathers. ... it really makes me laugh sometimes. You go talk to this one person and they say, 'By the way, this is my sister so-and- so and this is my aunt so-and-so.'

10. Statistics Canada: Income in Canada, CD-ROM, Table T802. 
An immigrant assembler:

If you are new here in Canada, your English is not very strong. Even if you go for interview, you can be an excellent specialist, but if you don't know English, nobody is going to give you the job. In most cases I think this [hiring through ethnic networks] is working.

Magna also recruits skilled workers from low labour standard countries, and many of these skills have limited transferability. For example, Magna recruited many white skilled trades workers who left South Africa after the apartheid regime fell. In engineering, as well, there has been heavy reliance on non-native-born recruits and internal recruitment. Many do not have the same level of formal qualifications that similarly skilled workers have in Big Three assembly plants. An estimated one quarter of these plants' skilled trades workers come from the shop floor through internal recruitment and training, much of which is based on European standards that are not widely recognized in Canada. An estimated half of the positions in engineering are filled by less professionally credentialed employees who worked their way up. Most supervisors come from the ranks of production workers and tend to have fewer formal skills than those recruited externally. Magna provides extensive training in areas including technical skills, apprenticeships, human resource management and supervision.

\section{UNION AVOIDANCE AND LABOUR-MANAGEMENT COOPERATION}

We have sought to explain how, despite highly Taylorized labour processes, Magna's HRM model has, with few exceptions, not only precluded unionization and contained worker resistance but also fostered surprising labour cooperation with corporate competitiveness goals. Magna's strategy combines 'soft' management techniques and an ethos of labour-management reciprocity and interdependence, together with rewards that are contingent on worker cooperation. Taylorist alienation, which might otherwise promote unionization, is assuaged by modest extrinsic rewards and high levels of cohesion. Union avoidance is embedded in a strategy of what could be called "unite and rule" that eschews exploitation of workplace divisions based on skill, ethnicity and gender. Cementing this cohesion is an ethic of cooperation among workers and between workers and managers, framed by Magna as an "employee entrepreneurial culture."

As noted, Magna's Open Door Policy includes a grievance system that integrates elements of worker voice and representation, and provides a sense of fairness. Magna's success at avoiding the kind of labour-management adversarialism that normally underlies unionization in Canada, the US and elsewhere, is indicated by the fact that most issues are resolved by work 
groups and supervisors as 'problems' before they become 'grievances.' Legitimation of managerial goals is further inculcated by communication systems that encourage active employee cooperation to achieve Magna's competitiveness requirements, and hence greater job security and remuneration. These cultural and organizational dimensions of union avoidance are complemented by important material inducements including remuneration via pay-for-performance systems, individual and small group bonuses, and collective incentives, notably via profit sharing.

Internal and external labour markets strongly support this unionavoiding HRM strategy. The main internal factor is the large tier of temporary labour in the plant which provides Magna with numerical flexibility, and permanent workers with a buffer against layoffs. Key external factors are the disciplinary effects of the vulnerability of small plants to competitive market pressures, and workers' experience of lower paid, 'bad' jobs in external labour markets, both foreign and domestic. To an important degree, this external labour market coercion substitutes for management coercion in eliciting worker cooperation by masking much of the power relation between managers and workers, transforming it into the impersonal, naturalized discipline of 'competitive' forces.

The result has been the creation of work-group and plant-level identities that are strongly congruent with management productivity objectives and inconsistent with union adversarialism that might contradict these objectives. In contrast to a union consciousness built in important part around a competitive division between profits and wages, in this model corporate profitability goals do not appear as a zero-sum contest with worker interests in higher remuneration and better working conditions. Worker cooperation is understood as a 'common sense' condition of mutual economic survival rather than as an antagonistic, mutable power relation. Workers who internalize Magna's work ethos expect to receive "fair" treatment and respect from management, and many believe management has honoured this reciprocal relation. Magna's competitive success has lent legitimacy not only to particular managers but also to the norms of cooperation that characterize its workplace culture. Competitive success has sustained Magna's ability to distribute the material and security benefits stemming from its culture of reciprocal obligations between hard working managers and hard working workers.

At a societal level, much of the explanation for such labourmanagement cooperation is found in the decline of the post World War II class compromise that legitimated and stabilized unions that helped to limit worker resistance through improved wages and benefits. Stable union-based industrial relations were supplemented through state activism. The embedded liberalism of social safety nets and the moderating effects 
of counter-cyclical fiscal and monetary measures provided an important degree of socio-economic protection for many workers. The compromises in the workplace and in society provided politically constructed havens for many workers. ${ }^{11}$

For over two decades, unionized labour relations models have eroded as the Canadian economy has become more open to international competitive pressures, particularly through trade liberalization, state deregulation and the liberalization of capital flows. Declining private sector union density, and major recessions in the 1980s and 1990s are important factors in the increasing exposure of larger numbers of workers to harsh labour markets. Labour markets have become more unequal and fractured as "good jobs" have declined and "non standard" part time, impermanent, and other contingent employment has increased (Wells, 1997; Vosko, 2006). This has been assisted by erosion of the social wage (most notably unemployment insurance, see McBride, 1992) and of labour rights and standards (Panitch and Swartz, 2003). In this context, workers' capacities to improve their pay and working conditions through their own usually union-based collective resistance have been thwarted by pressures well beyond plant-level labourmanagement relations. The increasing vulnerability of many plants to competitive forces has helped to deprive workers and their unions not only of collective leverage but also of the sense of opposition to profit goals that would be needed to contest Taylorized job structures. Industrial politics has become less focussed on union-centred adversarial worker-employer relations and more on "the "rational' tyranny of capital mobility over the collective worker" (Burawoy, 1985: 150). As a result, industrial politics and its prime manifestation, adversarial unionism, tends to be subsumed by market competition.

This dismantling of the unionism-legitimating postwar accord, and the weakening of the national economic autonomy on which it was predicated, has opened a new phase of corporate welfarism and company unionism (Jacoby, 1997). As Jacoby has argued, corporate welfare capitalism did not die out in the 1930s Depression but rather adapted to become a significant industrial relations current based on new forms of employee involvement and remuneration in non union workplaces (Jacoby, 1997). Magna is one model of this return to the corporate manor for "good workers." The Open Door Policy and other mechanisms of conflict resolution are similar to those promoted by the welfare capitalist movement of the early to mid $20^{\text {th }}$ century (Nelson, 1975; Wells, 1995). The Magna model substitutes managerial persuasion and cooptation for coercion, informal relations for

11. These protections were disproportionately enjoyed by unionized, male, "white" workers. 
formal labour-management relations, and individualized remuneration for more collective compensation.

The central problem this model poses for labour politics is the location of power: the main constraints increasingly shaping worker subordination in many workplaces are transnational competitive forces. These constraints (e.g., the North American Free Trade Agreement, the World Trade Organization, and a plethora of bilateral trade arrangements) are impossible to address effectively at the workplace level. As an example of hyperdecentralization of industrial relations to the plant level, the Magna model is both a symptom and cause of the erosion of labour politics. The roots of this decentralization of industrial relations to the level of workplace relations were present in the postwar accord itself, which was built around a multitude of local collective agreements, and was largely restricted to highly unionized core labour markets. The unravelling of the accord has reinforced this union decentralization and provided stimulus for the Magna model.

The consequences of such a model for labour politics and unionism are significant. When workers' identities are almost exclusively at the level of their firms, workplaces, and work groups, there is a corresponding diminution of a sense of their collective interests as workers in particular industries (the basis of industrial unionism) and as a class (the basis of social democratic and other forms of labour politics). As capital becomes more concentrated, and labour becomes more fragmented, the power imbalance between the two tends to grow. Marx was certainly correct about the tendencies toward increasing concentration of capital, but he did not foresee that tendencies toward the concentration of capital would be associated with such decentralization of production. This decentralization contradicts expectation that the large scale massing of workers in interdependent production processes would be necessary for effective worker mobilization of unions, social movements and political parties.

Renewal of unionism, particularly more adversarial forms of unionism, cannot take place only at the level of the workplace or individual firm because, in the context of contemporary labour market restructuring, this is where much of the logic of partnership is generated. Many worker accommodations with management that are taking place in both union and non-union workplaces reflect major changes in the balance of class forces beyond the workplace and the firm, which powerfully condition the turn toward more cooperative unionism and to non-union models at the level of the workplace.

These same forces can also provide conditions for the potential rise of a new phase of labour militancy and the renewal of more adversarial forms of unionism. The increasingly de-regulated nature of many aspects 
of market competition which exposes firms to increasing competition also exposes workers to extreme labour market precariousness. Magna's success at union avoidance is highly dependent on its ability to provide a certain degree of security and remuneration. This hinges in important part on the firm's ability to remain competitive, which among other things depends in turn on macro-level political and economic conditions that are well beyond corporate control. In this context, the previous phase of welfare capitalism may prove instructive. According to historian David Brody, the demise of early twentieth century welfare capitalism in the US came less from contradictions at workplace and company levels and more from the "extraordinary turn in the business cycle" that generated the 1930s depression (Brody, 1968). Similarly, historian Stuart Brandes argues that although workers' responses to welfare capitalism were more mixed, it was the Depression that "terminated the movement" as "welfare companies drew their belts ever tighter and reduced or eliminated expenditures on a variety of welfare activities" (Brandes, 1984: 142). Absent evidence that 'boom and bust' tendencies of markets are abating, it is unreasonable to expect that major recessions can be avoided indefinitely. As in the 1930s, this can generate a new impetus for the development of working class political strategies.

Even short of a major downturn in the economy, new working class political strategies might emerge at Magna. Currently, workers' vision of what is possible at Magna is very much controlled by management. A clear articulation of an alternative vision, one that offered workers security based on years of service, empowerment based on formalized agreements, and a pension plan less vulnerable to Magna's continued success might resonate with a large number of workers. This might be particularly so given the Magna model presupposes continuing outsourcing from largely unionized assembly plants and continued success in the highly competitive parts sector. In a context where this cannot be assured, it is likely that the job security and wage levels of permanent workers would be endangered, and the high-risk nature of the deferred profit sharing plan would be exposed. In such a scenario, with its profit margins being squeezed at a time when retirements loom for larger proportions of its workforce, it may become difficult for Magna to respond to employee demands for security. The lack of seniority and transfer rights between plants could become sources of labour-management conflict. Magna might be hard pressed to respond to the needs of an aging workforce, such as more light duty jobs before retirement and reasonable income after retirement. When management is less able to respond to worker demands, mechanisms of worker voice that are central to the Magna model may also become vulnerable. How, for example, would management be able to make the Worker Advocate system work 
under such conditions? It is logical to expect that such contradictions could weaken some of the pillars of labour-management reciprocity that have been the foundation of workers' cooperation with, and active dedication to, productivity and quality improvements. All of these suggest a potential undermining of the preconditions for union avoidance, particularly given management's reliance on highly Taylorized labour processes. When even the most stable plant-level industrial relations models provide only temporary havens for workers, prospects for renewal of unionism cannot be gainsaid.

Thus, after two decades of neo-liberal market restructuring in Canada and the US, and largely unsuccessful attempts by unions to organize Magna plants, both the United Auto Workers and the Canadian Auto Workers are currently engaged in management-initiated discussions to unionize Magna plants. This raises questions concerning management's view of the sustainability of its HRM model. It may also point to the changing nature of union-management relations as unions become more directly involved in promoting the competitiveness of firms with which they bargain.

\section{REFERENCES}

AdLer, Paul. 1992. "The Learning Bureaucracy: New United Motor Manufacturing Inc." Research in Organizational Behavior, 15, 111-194.

Anderson, Malcolm and John Holmes. 1995. "High-skill, Low-wage Manufacturing in North America: A Case Study from the Automotive Parts Industry." Regional Studies, 29, 655-671.

APMA. 2003. Automotive Parts Manufacturers' Association 2002 Compensation and Human Resources Practices Survey - Final Report. Toronto: APMA.

Appelbaum, Eileen, Thomas Bailey, Peter Berg, and Arne L. Kalleberg. 2000. Manufacturing Advantage. Ithaca: ILR Press.

Bengtsson, Lars. 1999. "ABB in Sweden." Being Local Worldwide: ABB and the Challenge of Global Management. J. Bélanger et al., eds. Ithaca: Cornell University Press, 156-178.

BergGren, Christian. 1992. Alternatives to Lean Production. Ithaca: Cornell University Press.

Beynon, Huw. 1975. Working for Ford. East Ardsley, England: EP Publishing.

BRANDES, Stuart. 1984. American Welfare Capitalism, 1880-1940. Chicago: University of Chicago Press.

BRoDy, David. 1968. "The Rise and Decline of Welfare Capitalism." Change and Continuity in Twentieth-Century America: The Twenties. J. Braeman et al., eds. Columbus: Ohio State University Press.

Brulin, Goran and T. NiLSSON. 1997. "Sweden: The Volvo and Saab Road beyond Lean Production." After Lean Production. T. Kochan et al., eds. Ithaca: Cornell University Press, 191-204. 
Burawoy, Michael. 1985. The Politics of Production. London: Verso.

Cusumano, Michael. 1985. The Japanese Automobile Industry. Cambridge: Harvard University Press.

Foulkes, Frank. 1980. Personnel Policies in Large Non-Union Companies. Englewood Cliffs, N.J.: Prentice Hall.

GRAHAM, Laurie. 1996. "The Myth of Egalitarianism." North American Auto Unions in Crisis. W. Green and E. Yanarella, eds. Albany: State University of New York Press, 65-80.

Holmes, John, et al. 2005. "Innovation in the Automotive Tool, Die and Mould Industry." Global Networks and Local Linkages. D. Wolfe and M. Lucas, eds. Montreal: McGill-Queen's University Press, 119-154.

Humphrey, John. 1982. Capitalist Control and Workers' Struggle in the Brazilian Auto Industry. Princeton: Princeton University Press.

InTIER Automotive. n.d. Dortec Employee Handbook.

JACOBY, Sanford. 1997. Modern Manors. Princeton: Princeton University Press.

JEFFERYS, Steve. 1986. Management and Managed. Cambridge: Cambridge University Press.

KATZ, Harry and Owen DARBISHIRE. 2000. Converging Differences. Ithaca: Cornell University Press.

Kochan, Thomas, Harry Katz and Robert McKersIE. 1986. The Transformation of American Industrial Relations. New York: Basic Books.

KoIKE, Kazuo. 1987. "Human Resource Development and Labor-Management Relations." The Political Economy of Japan. Volume 1. K. Yamamura and Y. Yasuba, eds. Stanford: Stanford University Press, 289-330.

Magna International. 2005a. 2005 Annual Report. Aurora, Ontario: Magna International.

Magna International. 2005b. Annual Information Form 2005. Aurora, Ontario: Magna International

Magna International. 2006. Annual Information Form 2006. Aurora, Ontario: Magna International

MCBRIDE, Stephen. 1992. Not Working. Toronto: University of Toronto Press.

MCBride, Stephen and Russell Williams. 2001. "Globalization, the Restructuring of Labour Markets and Policy Convergence." Global Social Policy, 1 (3), 281-309.

Nelson, Daniel. 1975. Managers and Workers. Madison: University of Wisconsin Press.

Panitch, Leo and Donald Swartz. 2003. From Consent to Coercion. $3^{\text {rd }}$ ed. Toronto: Garamond Press.

PIORE, Michael and C. SABEL. 1984. The Second Industrial Divide. New York: Basic Books.

Ross, Andrew. 2003. No-Collar. New York: Basic Books.

SABEL, Charles. 1994. "Flexible Specialisation and the Re-emergence of Regional Economies." Post-Fordism. A. Amin, ed. Oxford: Blackwell, 101-156. 
STEWART, Alex. 1989. Team Entrepreneurship. London: Sage.

Vosko, Leah, ed. 2006. Precarious Employment. Montreal: McGill-Queen's University Press.

Wells, Donald. 1995. “Origins of Canada's Wagner Model of Industrial Relations.” Canadian Journal of Sociology, 20 (2), 193-255.

Wells, Donald. 1996. "New Dimensions for Labor in a Post Fordist World." North American Auto Unions in Crisis. W. Green and E. Yanarella, eds. Albany: State University of New York Press, 191-207.

Wells, Donald. 1997. "Why Canada Needs an Active Jobs Policy." Policy Options, 18 (3), 35-39.

WELLS, Donald. 2001. "Labour Markets, Flexible Specialization and the New Microcorporatism.” Relations Industrielles/Industrial Relations, 56 (2), 277-304.

Zuboff, Shoshana. 1988. In the Age of the Smart Machine. New York: Basic Books.

\section{RÉSUMÉ}

\section{Quand les entreprises se substituent au syndicalisme d'opposition : le marché du travail et la gestion des ressources humaines chez Magna}

Magna International, avec un chiffre d'affaires de 22 milliards de dollars, passe pour le fournisseur le plus diversifié au monde dans l'industrie de l'automobile et emploie 82000 personnes dans 224 usines, réparties dans 21 pays. Au Canada, avec ses 22000 employés dans 61 usines, Magna est l'employeur le plus important dans le secteur de l'automobile. Son succès repose en grande partie sur sa stratégie de relations du travail, qui demeure presque totalement sans syndicat. Son habileté à tenir le syndicalisme à distance réside dans son modèle de gestion des ressources humaines, qui comprend des mécanismes d'expression des salariés et de solution de conflit, jouant un rôle de substitut aux fonctions syndicales de représentation et de règlement des griefs. Jusqu'à un important degré, les désaccords sur la productivité du travail et du contrôle managérial sont transformés en problèmes susceptibles d'être résolus entre les travailleurs. Le modèle de Magna inclut une politique de rétribution en termes de compensation monétaire, de promotion et de sécurité d'emploi, qui prend en compte les attitudes positives des travailleurs à l'endroit des objectifs de productivité et de qualité. Les cultures de réciprocité patronale-syndicale dans les usines sont enrichies par un réseau corporatif décentralisé, où chaque usine fonctionne comme un «centre de profit » quasi indépendant. 
Au Canada, Magna établit ses usines dans des marchés du travail semipériphériques, où les salaires et la sécurité d'emploi sont faibles et où le coût de la vie est raisonnable quand on le compare à celui des régions urbaines. Il faut ajouter que cette entreprise recrute un grand nombre d'immigrants. Ces politiques de marché du travail ont contribué à l'élaboration d'un modèle sans syndicat de gestion des ressources humaines fort, cohérent, compliqué. C'est là un modèle qui cadre bien avec le type actuel de relations en l'absence de syndicat et qui prend de l'ampleur en mettant l'accent sur la culture d'entreprise, sur des systèmes de communication à l'échelle de l'entreprise, sur des équipes de travail bien encadrées, des taux de salaires au-dessus de la moyenne, des arrangements salariaux flexibles et des cheminements de carrière individualisés. Ce modèle est influencé par la contrainte croissante du marché du travail et de la concurrence qui s'ensuit pour des emplois entre les travailleurs et qui s'intensifie.

En cherchant à connaître les raisons qui ont permis au procès de travail hautement taylorisé d'éviter la syndicalisation chez Magna, alors que la plupart des autres usines de fabrication d'autos au Canada, aux États-Unis et au Royaume-Uni sont syndiquées, cet essai soulève un certain nombre d'enjeux pour l'avenir du syndicalisme. Dans le modèle de Magna, les travailleurs vont se tourner vers la direction plutôt que vers les syndicats ou les partis politiques pour se donner «un refuge dans un monde sans âme ». Dans la mesure où des variantes du modèle de Magna deviennent de plus en plus typiques, cela indique un déclin des caractéristiques clefs des relations patronales-syndicales qu'on retrouvait au cœur de la politique ouvrière au Canada et ailleurs après la Seconde Guerre mondiale. Le démantèlement actuel de l'accord légitimant le syndicalisme d'aprèsguerre et l'affaiblissement de l'autonomie de l'économie nationale qui lui servait de fondement ont favorisé l'apparition d'une nouvelle phase de «firme-providence» et de syndicalisme d'entreprise. Magna personnifie ce modèle d'un retour aux bonnes manières envers les « bons travailleurs ». Ce modèle veut remplacer la coercition par la persuasion, les relations du travail formelles par les relations humaines, la rémunération sur une base collective par un régime de rétribution individualisée.

Le problème principal que pose ce modèle à la politique ouvrière est le lieu du pouvoir. Les principales contraintes qui, de plus en plus, viennent encadrer la subordination des travailleurs résident dans les pressions de la concurrence transnationale, qu'elles soient réelles ou non. Ces contraintes, qui se voient renforcies par la présence de l'Accord de libre-échange nord-américain, de l'Organisation mondiale du commerce, et d'un éventail d'accords commerciaux bilatéraux, ne peuvent être traitées de manière efficace sur les lieux mêmes du travail. Tout en s'affichant comme une hyper-décentralisation des relations du travail au niveau de l'usine, le 
modèle de Magna se présente à la fois comme un symptôme et une cause d'un effritement de la politique ouvrière. Les racines de la décentralisation des relations du travail se trouvaient dans l'accord même d'après-guerre, qui était composé d'une multitude de conventions collectives locales dans les marchés primaires du travail fortement syndiqués. L'effilochement de l'accord est venu renforcir la décentralisation du syndicalisme et a donné une impulsion au modèle Magna.

L'impact d'un tel modèle sur la politique ouvrière et le syndicalisme est important. Au moment où les identités ouvrières se développent presque exclusivement au niveau des usines, des lieux de travail, des groupes de travail, il survient une diminution du sens de l'intérêt collectif des travailleurs dans les secteurs de l'industrie (la base du syndicalisme d'affaires) et quand on considère ces derniers comme classe sociale, c'est la base même d'une démocratie sociale et d'autres types de politique ouvrière qui est en cause. Un regain des formes antagonistes du syndicalisme ne peut se produire seulement et uniquement qu'au niveau de l'entreprise individuelle ou du lieu de travail, dans un contexte de restructuration du marché du travail actuel. C'est de là qu'une logique de partenariat, de syndicalisme coopératif, de modèle sans syndicat, tire son origine.

Les mêmes forces peuvent offrir des conditions favorisant la montée éventuelle d'une nouvelle phase de militantisme ouvrier et de syndicalisme d'opposition. La nature de la dérégulation croissante de bien des aspects de la concurrence du marché fait en sorte que de plus en plus de travailleurs vont faire face à une précarité plus grande sur le marché du travail. Encore que Magna connaît un certain succès à tenir le syndicat à distance, cela est dû à son habileté à offrir un certain degré de sécurité d'emploi et de rémunération. Ceci vient entamer l'habileté de l'entreprise à demeurer concurrentielle, qui dépend en grande partie des conditions politiques et économique au sein de la société, ces conditions échappant au contrôle même de l'entreprise. Même à court d'un revirement de l'économie, des stratégies politiques pour une nouvelle classe ouvrière peuvent se développer chez Magna. Il s'agirait d'une vision alternative qui offrirait au travailleur une sécurité d'emploi basée sur les années de service, une attribution de pouvoir fondée sur des ententes formelles et un fonds de pension respectable. Dans un environnement où la capacité de Magna à soutenir la concurrence devrait s'amenuiser, la sécurité d'emploi et les niveaux de salaire des travailleurs permanents seraient menacés et la nature fortement à risque du régime de partage des bénéfices chez Magna serait également en danger. Dans un tel scénario, il peut s'avérer difficile pour Magna de rencontrer les exigences de sécurité d'emploi venant des salariés et les mécanismes d'expression des travailleurs deviendraient vulnérables. De telles contradictions peuvent affaiblir les piliers de la réciprocité patronale-syndicale, qui ont jusqu'ici 
conforté les travailleurs dans leur dévouement à l'amélioration de la productivité et de la qualité chez Magna. Elles peuvent également miner son modèle d'évitement du syndicalisme. Alors même que les modèles les plus forts de relations du travail au niveau des usines peuvent seulement offrir des refuges temporaires de sécurité d'emploi pour les travailleurs, des possibilités d'un regain du syndicalisme sont indéniables. 